\title{
Kosovo and the end of war
}

\section{Introduction: deviant voices}

NATO's bombing campaign in Kosovo and the refusal of most Western leaders to regard it as war have prompted numerous questions about the nature of this episode in recent European history. How should 'Kosovo' be categorised? Can it be covered by the usual linguistic repertoire, or does 'Kosovo' testify to the fact that 'war' has become conceptually inapplicable?

For most observers the term 'war' remains good enough. In their view, war is well and alive. The bombing campaign in Kosovo may not correspond to the Clausewitzian definition of war, but war antedates the modern state by a good number of millennia, and is therefore more than the continuation of statist policies by other means. Hence, the concept's transcendental nature gives it the power to bridge even significant temporal and spatial variations. In mainstream strategic thinking, Operation Allied Force does not stand out as an exceptional case in the history of armed conflict, and 'war' has therefore been used to label it without too much hesitation. Without doubt, collective violence has been employed, which allows 'Kosovo' be referred to as a war in this basic sense. With only a few exceptions, it is therefore still claimed that the Kosovo encounter has featured too few irregular and asymmetrical aspects to undermine the contingent character of war. Deviant voices can still be silenced.

Nevertheless, doubt about this orthodox reading of 'Kosovo' is mounting. Some critics now claim that 'Kosovo' just does not fit the standard categories of armed conflict and war, and that many irregularities have to be studied. These critics refuse to adhere to orthodox vocabularies and call for new analytical conventions that go beyond the accepted mainstream. They concede that coercive elements have indeed been involved in the Kosovo campaign, including the collective use of violence, but that there are many features of 'Kosovo' that radically deviate from what we traditionally have come to understand as 'war'. The distinctions and borderlines that have 
over time helped to carve out the concept of war (setting it apart from non-war) now seem to be faltering. A previously well-delineated and uncontested concept, 'war' no longer seems to be its good old self, the critics claim. 'Kosovo' therefore not only sets in motion a conceptual transition by breaking essential boundaries, but it may well be indicating a full-fledged conceptual crisis which needs to be reflected in the terminology that is to be used to describe these new phenomena.

'Kosovo' therefore signals a profound ontological clash, which has turned war into an openly contested concept. War has become increasingly debatable; it has become a moving target that appears to be losing its name. For Western policy makers and analysts this is especially disconcerting, since this emerging conceptual ambivalence applies not only to remote armed conflicts on the international system's periphery, but now seems to have infected the centre of Europe as well.

My aim here is to probe this breach in the discourse on war. The emerging clash of concepts is used as a vantage-point for an inquiry into the discursive strength of the concept of war in its different articulations. I ask how and why this concept is being rendered open to doubt? What is the significance of the various efforts of re-articulation; and what efforts are being undertaken to close this uncomfortable debate prematurely? In order to place this debate in perspective, I first review the unfolding of the concept of war during recent years. Such an inquiry is necessary since some of the arguments presented in the context of 'Kosovo' feed on previous claims of 'endism', i.e. that modern war seems to be withering away. This essay therefore argues that war is dying out, as it were, and that it is this change in the transcendental nature of war which has opened up space for doubt concerning the 'established truths' about conflict in general. This shift allows previously invisible and marginalised views to come out into the open.

However, it is also possible to think that the Kosovo debate - and the uncertainty about the core terminology - actually involves a broader problem. In fact, it could point beyond 'endism' (be it the end of war, the state, or other central planks of modernity). The search for new terms further undermines the central tenets in the established discourse on war, and may well contribute to the legitimising of new ones. What is underway may not be just the faltering of traditional categories but the emergence of new ones, and these rewritten concepts are by no means neutral and descriptive in essence. These efforts are elements of a process of signification and legitimisation which may be part of the formation of a new discursive order. We should therefore ask ourselves what the Kosovo campaign was really about, and, more generally, what such a reconfiguration of war would imply for the emerging NEO? What are the discursive consequences of these new interpretative schemes, and how do they contribute to the shaping of new identities, subjectivities and social order? 
These questions are posed since we need to know what kind of vocabulary we should (and can) use to describe an event like 'Kosovo'. It is of particular importance because our understanding of war has been central to the story of sovereign authority and modern statehood. The aim of this essay is therefore to map the alterations in the vocabularies used to describe 'Kosovo' by focusing on the productive aspects of war. I argue that this concept is changing rapidly and dramatically, and I try to trace the subjectivities and particular social formations that hinge on such a change.

\section{War: a floating signifier?}

Taking into account that many of the established features of the international system now tend to appear less natural, authorised and permanent, it is hardly surprising that basic questions concerning war have been problematised as well. It is recognised that war is not a permanent and unchanging principle or institution, but rather a social practice with its own history. Quincy Wright has argued that modern war 'rests upon an elaborate ideological construction maintained through education in a system of language, law, symbols and values'. ${ }^{1}$ War is a practice with typical modes of performance; it is historically constructed and (therefore) variable. War is an essential part of an international system dominated by states whose sovereignty is (or has been) the prime constitutive principle. War's historically variable modes of performance are closely linked to the nature of the political system itself, whereas war has also been constitutive of the political framework in which the performance occurs. With this in mind, war is increasingly approached - to use a term introduced by Ernesto Laclau and Chantal Mouffe - as a 'floating signifier'. 2

It may well be that the modern project can no longer muster the strength to anchor the concept of war and offer it a privileged, distinct place and role within the international system. During the twentieth century, modernity has defined the legitimate understanding and role of war, and has furnished it with a temporal and spatial permanence. This effort has not, primarily, been one of trying to do away with war, but can perhaps be better described as an essential aspect of modern inter-state relations. It is precisely the recognition and delineation of the sphere of war that has been conducive to a certain 'taming' of war, and, more generally, to the delineation of the unknown. As an unproblematic given, war has ratified and sanctioned the establishment of homogenous and stabilised 'insides', while deferring difference and contingency to the 'outside', i.e. the sphere of anarchy and unpredictability. By defining the 'outside' as the space of war, modernity has made the world of politics readable and instructive. The modern framing of the inside--outside dyad has been so firm and uncontested that it has 
become possible to consider war as an 'institution', or a 'regime', which also allows us to use such generalisations as the 'war-system'.

The distinction between the spheres of war and peace (i.e. the domestic intra-state realm) has served as the basis for border drawing in general, and allowed the establishment of divisions between order-anarchy, cosmos-chaos, we-they, self-other, inside-outside, domestic-foreign, friend-foe, and a long list of other binary oppositions. ${ }^{3}$ Anchoring war has brought about ontological security through stable social identities. The idea of two different political spaces in the modern world of sovereign states - one within states and another between states - has also made it possible for international relations (IR) theory to comport itself as a theory of survival, while political theory and law have been reserved for questions dealing with social order, the organisation of the 'good life', as well as the notions of 'progress' and 'history' through cumulative scientific and political achievements.

However, the widening search for alternative expressions now confirms that the concept of war is in trouble. Edward Luttwak, for example, has coined the expression of 'postheroic warfare' by distinguishing between traditional and novel forms of war. ${ }^{4}$ Chris Hables Gray uses the more general term 'postmodern war', whereas Mary Kaldor prefers the more limited notion of 'post-Clausewitzian war'. ${ }^{5}$ Richard Mansbach and Franke Wilmer may be closer to the 'endism' debate with their notion of the 'end of the Westphalian period', a term closely related to the ideas of John Mueller and Christopher Coker on the fundamental 'obsolescence of modern war'. ${ }^{6}$ Some concepts related to war which for a long time have been pushed to the sidelines - such as the 'just war' - now seem to be resurfacing.? The search for alternative vocabularies - either denoting 'endism' or attempts to provide novel labels for new kinds of (armed) conflict - confirms that conceptual destabilisation is having its effect. The central ingredient of the emerging counter-discourse on war is that war and violence are now increasingly defying the inside-outside nexus, thereby questioning the centrality of the state and the continued relevance of the story of modernity.

Apart from the challenge of 'Kosovo', war (like the notion of sovereignty) has become vulnerable to the ongoing pressures of globalisation and the complementary move of localisation. This should not come as a surprise, since the disregard for historical and cultural articulations in this connection has been accompanied by an eruption of contingency. The arrival of complex and ambiguous forms of armed conflict implies that traditional political vocabularies no longer serve as reliable points of reference. They are no longer helpful in drawing the inside-outside borders that have shaped our conventional understanding of what wars - and, more generally, international relations - are (supposed to be) all about. Kalevi J. Holsti has therefore claimed: 'War today is not the same phenomenon it was in the eighteenth century, or even in the 1930s. It has different sources and takes on significantly different characteristics. ${ }^{8}$ 
Some critics of the traditional approaches to 'war' - including the military historian Martin van Creveld - even argue that the concept should be consigned to the dustbin of history. This claim rests on the observation that, over the last few decades, inter-state war has become improbable. Traditional 'war' has become the ultimate exception to the rule, rather than the essential (and even constitutive) component which defines the very nature of international politics. With the vanishing of (military) violence, security has become less of an issue, opening up space for other arguments and concepts integration, for example - which are now allowed to take the initiative in organising the political scenery. The ongoing debate on the 'end of war' illustrates and supports this change. Coker argues that humankind 'may have been reprieved from the undertow of violence which marked the twentieth century'. ${ }^{9}$ Van Creveld claims that a 'ghost is stalking the corridors of general staffs and defense departments all over the developed world - the fear of military impotence, even irrelevance'. ${ }^{10}$ Van Creveld is supported by Michael Mandelbaum, who argues that it is 'possible that not only war protracted struggles among great powers with revolutionary consequences for international politics - but even modern war - the use of mechanised weapons in formal battles between the professional armed forces of sovereign states - is dying out'. ${ }^{11}$

However, the 'endism' debate is limited to traditional inter-state war, which, as an ultimate instrument of power-politics, no longer dominates the security environment across large areas of the world. Even though 'war' continues to offer IR a unifying code and language (despite the fact that armed conflict is relatively rare and is geographically unevenly spread), it is no longer read as a structural necessity, which has opened the way for new organising principles and departures. The grand narrative of regular and instrumental major war has been replaced by a pattern of violence which is more localised and less easy to define as either 'internal' or 'external'. ${ }^{12}$ Students of global politics are therefore faced with a choice: should they continue to label these (armed) conflicts 'wars', even in a very general meaning of the word, or should they develop new vocabularies more in tune with the determining aspects of these new kind of conflicts?

Max Singer and Aaron Wildawsky have suggested that the concept of 'war' be divided into two different spheres. ${ }^{13}$ They argue that a certain differentiation is in order since inter-state relations are no longer imbued with anarchy and that broad 'zones of peace' exist in parallel to 'zones of turmoil'. Clearly, there is no peace in the absolute sense as the political scene is coloured by manifestations of political violence such as terrorism, civil strife, massacres and, occasionally even genocide. Today's violence is often initiated by non-statal actors, killing soldiers as well as civilians and frequently organised in non-territorial ways. Mark Duffield and Mary Kaldor have further argued that contemporary conflicts usually are not conducted in a statist manner and not limited to a clear territorial space. ${ }^{14}$ These conflicts 
now tend to blur the prevalent inside-outside logic, since they appear in small pockets of conflict, crossing statal lines of demarcation. In terms of temporality, conflicts may be characterised by their longevity and protracted nature, or they may take the form of occasional clashes and outbursts with a shorter duration.

But the unravelling of modern war also includes the language itself, since we now tend to talk about 'strife', 'low level conflicts', 'private and informal wars', 'wild zones', 'kalashnikov zones', 'no-go areas', 'pathological anarchies' and 'insurgencies'. Other new terms (such as N. Theyer's 'wars without reason', Alain Minc's zones grises - i.e. geographical and social areas where the rule of law does not apply - and Philip Cerny's notion of 'insecurity from below'), also indicate that essential changes are taking place. ${ }^{15}$

It therefore appears that the concept of war, in defying the desire for categorisation and definability, does not stay within the confines and the discursive principles of modernity. The image of statal actors aiming their military forces against each other, followed by combat between their organised armed forces - an image upon which the discourse of (modern) war basically rests - has been blurred. Patterns appear to be unfolding that go beyond any narrow conceptualisation of 'war', bringing about 'noise' instead of erasing it, and failing to draw clear boundaries by means of which we are able to identify and separate identities. ${ }^{16}$ Now that modern state-based faultines have lost much of their importance, the concept of war seems to be both debordered and rebordered. ${ }^{17}$ The inside-outside delineation of states is crumbling and no longer defines distinct coherent security spaces now that armed conflict is no longer part of the standard repertoire of Western politics. Instead, violent conflicts stand out as enclaves amid an otherwise rather peaceful environment, and within such a more mixed and complicated political pattern states stand out as one category of actors among many others. With conflicts no longer confined to armed struggle between statal actors, many states have gradually lost the primacy which they were supposed to have as the monopolists of legitimate violence and the guarantors of political order.

These deviations explain why the concept of war has become insecure and why basic questions about war have re-entered the political agenda. A number of redefinitions have occurred that signal an epistemic change in the discourse on war. There is no longer one dominant form of conflict that dictates what war is about, but rather a proliferation of particularisms. Previous knowledge, which has privileged state-centred perspectives and territorially bounded violence, now seems to be unable to contribute to our understanding of contemporary events. Consequently, 'war' is treated in a less coherent and dogmatic manner, and various interventions on its nature open up perspectives which previously were difficult to explore with any credibility. At the same time, it should be acknowledged that efforts to divorce oneself from traditional understandings of war remain the exception, rather than the rule, and they tend to remain exploratory in character. 


\section{War as usual}

How should we approach the Kosovo campaign against the background of war's increasingly uncertain meaning? Is 'Kosovo' to be read as 'war as usual', or do the critical voices have a more convincing story to tell on the basic nature of this event?

In general, the Kosovo campaign has only added to the problematising of our notion of what war is all about. It has certainly not encouraged a return to war as an unproblematic given, although there has been room for rather conventional interpretations as well. For quite a number of observers, 'Kosovo' has been 'business as usual', a conflict that should be framed in a traditional manner. In the view of (what probably is) the majority of analysts, no 'contamination' has occurred and the old register of concepts is considered both useful and sufficient. In this perspective, the concept of war is both self-evident and non-debatable; it dispels doubt and suggests that the name of the game has remained unchanged: simple and straightforward 'war'. This modern ontology of war still dominates the debate on Kosovo, where the story of the conflict is told in terms of order versus anarchy, whereby the principle of sovereignty continues to draw lines between friend and foe. In this perspective, war remains the ultimate boundary-making, and not boundary-breaking, form of political action.

One clear example of this traditional view is to be found in the recent writings of Ivo Daalder and Michael O'Hanlon, who read 'Kosovo' as a novel manifestation of the old story of 'order versus anarchy'. ${ }^{18}$ Adopting a Realist nomenclature, they talk about 'Kosovo' in terms of 'the path to war', 'losing the war', or 'winning the war'. They uncritically assume that the discursive strength of the classical notion of war remains intact and they are not troubled by the fact that in the case of the Kosovo campaign NATO achieved its objectives without a single combat fatality (at least on its own side). They also disregard the inequality of the actors in the campaign, or the absence of the usual mutual recognition of sovereignty, which during modernity has constituted warring factions and framed the idea of what war is (or should be) all about. Daalder and O'Hanlon concede that events have unfolded in a somewhat exceptional manner, but are not convinced that the traditional reading of the 'war' concept has been undermined by these irregularities, which would necessitate the use of alternative vocabularies to describe contemporary armed conflict. Like many other proponents of the 'war-as-usual' outlook, these authors agree that war takes a variety of forms, making it occasionally difficult to recognise. However, the possibility of war remains and continues to form the liminal condition against which international politics is being conducted. This is supposed to assure the traditional register of politics and security, and to confirm and stabilise its validity and relevance. ${ }^{19}$

Jenny Edkins arrives at similar conclusions, although she responds primarily to the way in which tropes such as the Holocaust and Nazism have 
been used to articulate humanitarian concerns during the Kosovo campaign. ${ }^{20}$ Edkins argues: 'What Kosovo represented was by no means the beginning of a new form of governance in which humanitarianism overrides state sovereignty, as liberal humanitarians argue.' She claims that 'Kosovo' has shown us a repetition of the old form of sovereign politics - a politics of exclusion, or a politics of the sovereign ban. She adds, however, that 'the sovereign power produced this time was NATO', i.e. the institutionalised entity being constituted was not a state (in opposition to other states), but a broader transatlantic community. ${ }^{21}$ Yet, Edkins claims that this change in spatiality and the emergence of a broader community do not imply that 'war', as a concept, has now become a misnomer.

By categorising these different authors, it appears that those who concur with the Serbian reading of the Kosovo campaign often have little doubt about the essence of the event. Their verdict tends to be clear: the bombing campaign has been a classic act of aggression, albeit one disguised as a call to construct a 'global village' and formulate its new rules. It has been seen as an infringement of the sovereign rights of an independent country and as an unjustified meddling in that country's domestic affairs. In this view, 'Kosovo' has been an 'aggression' on the part of the West and an attempt to bomb Serbia into submission. ${ }^{22}$ Clearly, these critical accounts also use the traditional conceptual repertoire of state-based sovereignty, territorial integrity and non-interference in the sphere of domestic affairs. 'Kosovo' was therefore a conflict over the preservation of Serbia's internal integrity and an attempt to keep Kosovo a part of the Yugoslav federation. In this reading of 'Kosovo', there is little doubt about what vocabulary should be employed to describe the essence of the event: it was seen as 'war as usual', whereby the notion of war is used to stabilise and fortify existing identities and political realities.

\section{Towards a higher order?}

But 'Kosovo' can be depicted differently. Michael Ignatieff, for example, has drawn attention to the conceptual deviancies and oddities of 'Kosovo', and argued that the conflict has been one of the first 'virtual wars'. He claims that many facets of 'Kosovo' have been kept hidden and that the public image of the conflict was markedly different from the 'reality' on the ground. Ignatieff is troubled by the concepts and the images that are now used, arguing that 'virtual reality is very seductive'. ${ }^{23} \mathrm{He}$ seems to be aware of the trappings of virtual war, with its own fables and representations based on self-righteous invulnerability: 'We see war as a surgical scalpel and not as a bloodstained sword. In so doing we misdescribe the instruments of death. ${ }^{24}$

But these 'make-believe' aspects of 'Kosovo' do not seem to have carried very far, although they were certainly there. One may argue that the nineteen 
NATO countries were not aiming to hide their true aspirations. Contrary to Ignatieff's suspicions, they were not trying to turn the 'real war' into something else by resorting to some linguistic subterfuge. On the contrary, they have aimed for genuine communication, but were often unable to get their message across since their line of argumentation clearly deviated from the traditional war-speak of modernity. In many ways, 'Kosovo' was all about safeguarding and enabling unhindered communication and exchange. It has stood out (here I follow Michael Shapiro's line of thinking) as a process in which war transcended its modern meaning by reaching out and expanding the domain of political action. ${ }^{25}$ NATO countries portrayed themselves as humanitarian champions enforcing respect for human rights. Since NATO did not label its campaign a 'war', it was already indicating that something new was underway. NATO's alleged civilisational aims called for new moral and legal criteria in order to pass judgement, which would, one could argue, call for a new military logic of action as well. But NATO's military actions were not exceptional; they did not even try to go beyond politics. On the contrary, they were part and parcel of a broader package of political aims, one that under normal circumstances is advanced by less violent means. To quote a representative statement from a NATO press release:

NATO is not waging war against Yugoslavia. We have no quarrel with the people of Yugoslavia who for too long have been isolated in Europe because of the politics of their government. Our action is directed against the repressive policy of the Yugoslav leadership. We must stop the violence and bring an end to the humanitarian catastrophe taking place in Kosovo. We have a moral duty to do so. ${ }^{26}$

For NATO countries, 'Kosovo' did not signal a real war. They did not believe that the discursive power of the concept was intact, or was in line with their aspirations. There was neither a declaration of war nor parades to mark its end. More importantly, for NATO, 'Kosovo' was about something quite different, since the classic Realist reasons for war fighting (the conquest of territory, oil, empire, or other 'sovereign rights') did not apply. These modern reasons for war were absent because the conflict in Kosovo centred around the pursuit of moral aims (rather than traditional politics) by other means. The vocabulary employed related more to the tradition of a just war (a notion that preceded the era of modern wars), which was firmly grounded in denationalisation and aimed to replace politics with the imperative of universal principles and virtue.

In positioning themselves in a context that was no longer premised on geopolitical logic, NATO countries argued that their political agenda was based not on power, but on values; it was grounded in the representation not of national interests, but of international responsibilities (which included the inviolability of human life). NATO found itself engaged in a new kind of cosmopolitan mission, entangled in a battle in which 'difference' was not 
necessarily interpreted as enmity. NATO countries took care not to define Serbia - and particularly not the Serbs as a people - as their enemy, and continued to stress that they were out to defend human rights and not to conquer the country. Their effort was not one of pursuing egoistical self-interest within a Hobbesian setting, but to fight what Ulrich Beck has labelled a 'postnational war'. ${ }^{27}$ Beck has labelled NATO's new political approach as 'military humanism', a phrase which tries to capture the breakdown of classical notions of war and tries to grasp the novelty of NATO's efforts. ${ }^{28}$ NATO's aim was to enforce respect for the values of a higher supranational order and community, thereby constituting NATO itself as well as its own sphere of security.

During the Kosovo campaign, the security of the Allied states themselves was not at stake, at least not directly. NATO countries were not in danger of being attacked and their borders or territorial integrity were not under threat. It therefore appears that the transatlantic community that was constituted by the Kosovo experience was based not on the presence, but rather on the absence, of the traditional argument of statal security. The entity being created was based on arguments that go beyond conventional readings of security since it was exempt from the logic of anarchy. In order to be present at all, the notion of 'security' had to adapt itself to the core constitutive themes of individual rights, exchange and openness. As Andreas Behnke has argued, the security argument was employed in a derivative and protective manner, rather than in a productive way. ${ }^{29}$ During 'Kosovo', the notion of security was deprived of its traditional linkages to sovereignty and instead referred to the safeguarding of an emerging non-sovereign community - one represented thus far by the idea of 'Europe'. Clearly, such an abstract referent object is no longer territorially bounded. The derivative nature of security, and the functions of such an argument in terms of border drawing, also implies that the Kosovo conflict turned into a kind of non-divisive war. It has been a conflict that defies bordering and thereby also the clear-cut classification of political space along modern lines.

\section{Dealing with a residual case}

More generally, the Kosovo move was conceptualised as a method to bring a residual case in line with the general requirements of the emerging postCold War system. 'Kosovo' was about constructing the new Europe, the configuration of a stable political sphere which extends the European project to cover some of its resistant fringes and to fend off subversive tendencies which tend to question the legitimacy of the 'new system'. In their efforts to legitimise their action, NATO countries have resorted to new vocabularies, using words and concepts different from the ones employed in the context of 'war', be it during the Cold War or its traditional predecessors. In doing 
so, the often propagated idea of a 'war against war' has acquired an altogether novel meaning.

Instead of leaning on the traditional state-centred repertoire, the Kosovo campaign was defended by arguments that border on idealism. Here, a group of Western countries was claiming that it was transcending its warlike past in favour of a broader collectivity, one of international collaboration where the rules of the game were no longer predicated on sovereignty and national interest. Such interests were still present, it was argued, but they were moulded and had gone through a civilising process. Beck has tried to capture this intriguing aspect of 'Kosovo' in his reference to the new notion of 'military pacifism' ${ }^{30}$ The bombing took place, it was claimed, to ensure respect for what were seen as the foundations of the post-Cold War order in Europe. NATO was not fighting for the sake of preventing Serbia from joining this new order or to exclude it from this new sphere of stability and 'non-war'. Rather, NATO's campaign was being conducted in order to ensure that this still fragile post-Cold War order could flourish and could, in future, incorporate Serbia as a possible new member. It was an effort to construct a new political spatiality which would go beyond the traditional us-them dichotomy. NATO saw itself confronted with a country which, due to unfortunate circumstances and bad leadership, had been isolated from the European democratic family of nations. Serbia (as well as Serbs) was not constructed as an outsider and made 'foreign'. Instead, it was depicted as an entity that defines the boundaries of 'our' community, and treated as a challenge - even as a case that could serve as a litmus-test to verify the very existence of that community. In other words, NATO countries gave up their sovereign right to decide upon the friend-foe distinction. Without the naming of enemies, and with the efforts of denationalisation, a system reaching beyond the modern script was provided by subjectivity.

The 'other' that was being constructed in this new kind of discourse was an echo, a faint reflection of the West's own non-civic past. In a way, NATO countries were bombing a mirror-image of their old selves. In this reading of the Balkan mirror, Serbia could hardly be depicted as a straightforward opponent, or as the 'enemy'. But it was also not viewed as a fullfledged sovereign entity, or as a dignified actor which deserved NATO's respect and could be placed on the same level as 'us'. Serbia was not located on the outside in order to reify old statal identities, or to confirm the traditional state-based system of international relations. This could not be done because the new cosmopolitan construction lacked an agreed upon external border which would allow for such a move.

The discrimination and singling out of Milosevic's Serbia therefore had to be based on its moral inferiority. This categorisation, one no longer premissed on a mediation between sovereign actors, was already present during the Rambouillet talks (of February-March 1999). The end result of the Rambouillet 'negotiations' could therefore only be a Western dictate. 
Serbia was nothing more than an object located within Europe's shared space; it was considered an inferior entity, a child that should be compelled to swallow a bitter medicine. Judgement on the scale of moral superiorityinferiority provided the rationale for treating Serbia as a body upon which NATO countries could actualise their self-endowed role as the guardians of a civilisation in the making. Serbia, as a problematic case, had to be 'Europeanised' without ousting it into the sphere of external 'otherness'. Instead of confirming and constructing the traditional inside-outside nexus (which would uphold the us-them distinction), the aim was primarily to achieve de-bordering and inclusion. In doing so, NATO was doing nothing less than turning 'war' into the opposite of its modern self.

In the context of 'Kosovo', the logic of enmity was not to be confirmed, but to be transcended. The friend-foe, self-other divisions were to be broken down by bringing Serbia in from the 'cold'. Serbia, as a deviant case, had to be patronised (even by rather harsh measures) into the community of 'civilized' states in Europe. Although this move was non-exclusive, it was also clearly not benign. The end result was therefore a unity and homogeneity premised on civilizational claims - one without an outside, since these claims were considered universal. In other words, the subjectivity which was being created owed nothing to the 'outside', and this absence of any kind of external debt to difference (such as the debt represented by a deviant Serbia), resulted in NATO's claims of its own inherent boundlessness.

\section{Averting the mirror image}

In their search for legitimisation, NATO countries premised their action on a new reading of 'Europe'. The American, British and French political leadership argued that NATO's aim was to prevent 'Europe' from returning to its old self - an entity fraught with Realpolitik and power-political conflict and war. The leadership argued that a liminal case at the fringes of the new system had to be sorted out. The difference of a stranger, which functioned as a kind of 'internal other', had to be tackled and 'normalised' in order to prevent the spread of this kind of deviant behaviour. Such behaviour had to be discouraged as it could undermine the social and political cohesion of Europe's new post-Cold War system based on human and political rights, openness and dialogue. Against this background, the concept of war was a misnomer, since the act of bombing was not a reversal to power politics, or 'war as usual'. Instead, it signalled something revolutionary: it represented (in temporal terms), a moment of becoming, overtaking the modern concept of war and substituting it for something new, unknown.

In a similar vein, the breach of old political habits was illustrated by the fact that the bombing took place without the approval of the United Nations Security Council, a body imbued with a power-political logic from 
which the 'New Europe' wanted to disassociate itself. International law, as interpreted by Amnesty International in its report on 'collateral damage', was equally refuted. ${ }^{31}$ Behnke has therefore argued that

the re-introduction of a discriminatory concept of war no longer rests on the normative and political efficacy, or are dependent upon, a legal-institutional 'legitimisation system.' Instead, the new formulation rests on the purported empirical 'facts of life' in international politics. Scientific knowledge about realities of international politics provides its legitimacy. ${ }^{32}$

Another way of putting it would be to say that NATO grasped the opportunity to re-engage itself with Europe's own history. Through 'Kosovo', NATO turned itself into an agent of more universal aspirations, trying to abandon traditional identities and assuming a far broader sense of 'we' than that of the various statal actors which were performing in the campaign per se. Instead of falling prey to history, NATO countries aimed at grasping the opportunity of making history by virtue of a set of superior civilisatory values. Such a moment of 'becoming' - instead of just concerning itself with sovereign 'being' - was made possible by Serbia's refusal to abide by such Western values. Therefore, to describe NATO's bombing as 'war' - at least from a NATO perspective - would be a misnomer and would even undermine NATO's effort to construct itself as a new transatlantic community.

'Kosovo' has helped to construct a new doctrine of international politics by trying to come to terms with the paradoxical interplay between the global and the local, and by carving out a new kind of political space which reaches beyond statal parameters. This new doctrine of humanitarian intervention is no longer 'modern' in the sense that it is not predicated on the notions of sovereignty, a clear line between inside-outside, friend-foe or self-other. Rather, it is premised on ambivalence and ambiguity, caused by the blurring and transcending of numerous political and conceptual boundaries, including those that are essential to the modern understanding of war.

Thus new terms had to be invented and applied in order to underline the difference with modern 'war'. Various neutral ones, such as 'campaign', 'operation', 'mission', 'strike', 'attack', 'intervention', 'coercive diplomacy' or 'struggle', were frequently employed; in other cases, NATO could simply resort to using technical jargon (such as Operation Allied Force.) But despite the many non-war concepts, NATO leaders found it difficult to come up with intersubjectively shared concepts that would get across their intentions and views in a credible manner. The notion of 'war' stood out as a fixed, even inflexible, term, making it difficult to ignore or overrule due to its long history and its still dominant position. This may explain why NATO spokesmen used the term 'humanitarian war', albeit somewhat reluctantly. ${ }^{33}$ The precise difference between 'war' and 'humanitarian war' remains hard to explain, although some discrepancy was certainly evident. 


\section{Conclusion: war as a stranger}

So, has war remained its 'old self', has it metamorphosed into something altogether new, or might it be even disappearing altogether? Is war still an integral part of inter-state relations, has it gained new meaning now that it is associated with the West's efforts to establish a neo-Kantian cosmopolitan community, or is it losing ground altogether through a radical change in its discursive power?

The debate on 'Kosovo' indicates that there is considerable uncertainty about war as a concept. Core actors have found 'war' an inapplicable notion and have refrained from using it publicly. A serious critique on the concept of war has surfaced, and alternative articulations are now frequently explored. The concept seems to suffer from being inherently modern in essence and hence out of tune with the emergence of a plurality of centres, altered borders, multiple meanings and fluid identities that increasingly characterise the post-Cold War European strategic landscape. War is no longer what it used to be, and there are obvious difficulties in adapting it to the new political circumstances, although it does not seem to be disappearing altogether. The concept has only limited discursive currency, although (perhaps through a process of inertia) some of it is still there. In order to trace its current position and to locate the source of some of its continued discursive strength, a triad of basic constellations may be outlined.

Firstly, one may argue that a broad sphere of non-war has now emerged. Within such a new constellation, war remains first and foremost a memory from the past. The security logic has lost its foothold, and politics no longer seems to be focused on averting war and purely military threats. Consequently, a broad repertoire of varied civil identities has surfaced which is detached from war and matters military. The unfolding of political space no longer hinges on securitisation but, as a discourse, on themes such as markets, media, technology and other arguments geared towards unifying rather than dividing peoples and communities. The realm of 'international relations' is changing in meaning since it no longer stands out as the domain of exception, as the state of emergency and the field of Realpolitik. Instead, it increasingly assumes the nature of 'politics as usual'. Security-related arguments appear - to the extent that they are there in the first place - in a 'soft' form and are relegated to the fringes of the system, to be tolerated only if they can be accommodated within the dominant set of border-breaking principles. The increasing use of the notion of co-operative security is a case in point.

Secondly, there is the sphere of classic war, which remains based on the modern story of states, sovereignty and territoriality. In this constellation, war is used to safeguard established identities that are cast in terms of unambiguous friend-foe relations, and is aimed at resisting subjugation to the global-local divide that threatens to dethrone war and classic security 
concerns as the core principles in the construction of political space. In many cases, the option of war serves the purpose of averting systemic change and avoiding the destabilisation of cherished entrenched identities. The sphere of war therefore constitutes a residual sphere with homogeneity on the inside and difference on the outside. In this sphere, threats of inter-state war remain credible and there is little need (and therefore little discussion) of introducing other referents.

Finally, there appears a sphere where old and new conceptions of war clash. It constitutes the sphere of 'uncommon' violence and new exceptional forms of war and armed conflict. In these cases, war appears to have escaped the confines of both modernity and the modern state, and is enmeshed in the dialectical interplay between local and global forces. In this sphere, the boundaries of war's discourse (in its modern meaning) are dissolving: the inside-outside divide of states no longer seems to constitute coherent and alternative security spaces. As a concept, war is being undermined, encouraging the search for alternative terms and articulations. Security no longer circumscribes spheres that are confined to blocs and states, but imagines and creates areas of overlapping entities defined by multiplicity. War and violence assume a limited and enclaved quality in the context of a broader logic that pertains to the unfolding of international politics and political space in a more general sense. War does not stand out as a normal state of affairs within a domain marked by its very presence, but occurs as an exception and a stranger. War represents a form of discontinuity of politics-as-usual, with war unfolding as something unexpected in the midst of a broader setting coloured by the general absence of securitisation. The international community is now considered to have become the norm, whereas local conflicts are increasingly depicted as exceptions conducted by 'outlaws' (or by so-called 'failed states'), and are therefore subject to West-mediated remedies and normalisation.

The pluralism of the Kosovo campaign and the variety of interpretations concerning its essence make it difficult to place 'Kosovo' into perspective and to offer it a distinct location within the three alternative spaces outlined above. 'Kosovo' is neither a constitutive part of 'war' as a new constellation nor as wearing its traditional military battle gear. It allows itself to be interpreted from a variety of standpoints, new as well as old. It may be seen as war-as-usual, staying put and untouched by the forces of change, but it may also be interpreted as signalling - due to its many peculiarities - the very demise of modern war.

And yet the third alternative appears to be the most credible sphere of analysis. 'Kosovo' seems to represent a case where the logics of the new and the old are being played out simultaneously. A strong echo of the traditional notion of war remains present, whereby the 'old' seems to be resisting the 'new' and the incoming, albeit (perhaps) not very successfully. The Kosovo campaign seems to be imbued with aspects of these two rather different 
logics, and in order to figure it out, one has to bridge these different strands of thinking about war. 'Kosovo' indicates that the contemporary notion of war operates in multiple registers simultaneously, based on a dialectical process of opening up and closing down, of bordering as well as de-bordering political entities and communities, old and new concepts and ideas. Clearly, both of these contending aspects are present.

In Kosovo, war has transcended its modern meaning without becoming an integral part of the new and incoming, and without altogether leaving behind the old ideas of war. Defining 'Kosovo' is not merely providing war with a new referent or using more clearly differentiated conceptualisations. Above all, it has to be furnished with an ontology that reaches beyond the modern one. War has to be envisaged without the modern baggage that the concept still carries around, and by loosening up the conceptual ties to notions like sovereignty, statehood and traditional readings of security. But such a refiguring of war obviously has implications for a number of other concepts and practices associated with war. The events in Kosovo in 1999 exemplify war in its new disguise. 'Kosovo' stands for a site where a number of conceptual tensions, inherent in the clash between the old and the new, have been forced into the open, for everyone to see and so that no one can ignore them. 'Kosovo' therefore provides an opening for rethinking war, although the renaming of 'war' still runs against the numerous conceptual limitations set by the modern project. Luckily, some departures have now been made which may allow us to explore beyond what we know already.

\section{Notes}

1 Quincy Wright, Study of War (Chicago, IL, Chicago University Press, 1983), p. 356.

2 Ernesto Laclau and Chantall Mouffe, Hegemony and Socialist Strategy. Towards Radical Democratic Politics (London, Verso, 1995).

3 For an elaboration of the 'cosmos-chaos-argument', see Ola Tunander, 'PostCold-War Europe: Synthesis of a Bipolar Friend-Foe Structure and a Hierarchic Cosmos-Chaos Structure', in Ola Tunander, Pavel Baev and Victoria Ingrid Einagel (eds), Geopolitics in Post-Wall Europe: Security, Territory and Identity (London, Sage, 1997).

4 Edward N. Luttwak, 'Towards Post-Heroic Warfare', Foreign Affairs, vol. 74, no. 3 (May-June 1995).

5 Chris Hables Gray, Postmodern War: The New Politics of Conflict (New York, Guilford Press, 1997), and Mary Kaldor, New and Old Wars: Organized Violence in a Global Era (Cambridge, Polity Press, 1999).

6 Richard W. Mansbach and Franke Wilmer, 'War and the Westphalian State of Mind', paper presented at the conference 'The 350th Anniversary of the Peace in Westphalia', at the University of Twente (Enschede), 16-19 July 1998; John Mueller, Retreat From Doomsday. The Obsolescence of Modern War (New York, 
Basic Books, 1989), and Christopher Coker, War and the Illiberal Conscience (Boulder, CO, Westview Press, 1998).

7 Andreas Behnke, 'Democratic Peace Theory and the Renewed Turn Towards a Discriminatory Concept of War', paper presented at the ISA Annual Meeting (Los Angeles), 14-20 March 2000.

8 Kalevi J. Holsti, The State, War, and the State of War (Cambridge, Cambridge University Press, 1996), p. xi.

9 Christopher Coker, 'Post-Modernity and the End of the Cold War: Has War Been Disinvented?', Review of International Studies, vol. 18, no. 2 (July 1992).

10 Martin L. van Creveld, The Transformation of War (New York, Free Press, 1991).

11 Michael Mandelbaum, 'Is Major War Obsolete?', Survival, vol. 40, no. 4 (winter 1998).

12 Kaldor, New and Old Wars, pp. 69-74.

13 Max Singer and Aaron B. Wildawsky, The Real World Order: Zones of Peace, Zones of Turmoil (New Jersey, Chatham House Publishers, 1993).

14 Mark Duffielt, 'Post-Modern Conflict: Warlords, Post-Adjustment States and Private Protection', Civil Wars, vol. 1, no. 1 (spring 1998); and Mary Kaldor, 'Introduction', in Mary Kaldor, Ulrich Albrecht and Geneviève Schméder (eds), Restructuring the Global Military Sector: The End of Military Fordism (London, Pinter, 1998).

15 N. Theyer, 'Rebels Without a Cause', Far Eastern Economic Review, 27 April 1995; Alan Minc, Le nouveau Moyen Age (Paris, Gallimard, 1993); and Philip G. Cerny, 'Neomedievalism, Civil War and the New Security Dilemma: Globalisation as Durable Disorder', Civil Wars, vol. 1, no. 1 (spring 1998).

16 Mathias Albert, 'Security as a Boundary Function: Changing Identities and "Securitization" in World Politics', International Journal of Peace Studies, vol. 3, no. 1 (1998).

17 This point has been made by Michael Dillon and by R.B.J. Walker. Both Dillon and Walker endeavour to uncover the larger frame of international relations of which the concept of war has been an integral part during the modern era. See Michael Dillon, The Politics of Security: Towards Political Philosophy of Continental Thought (London, Routledge, 1997); and R.B.J. Walker, InsidelOutside: International Relations as Political Theory (Cambridge, Cambridge University Press, 1993).

18 Ivo H. Daalder and Michael E. O'Hanlon, Winning Ugly: NATO's War to Save Kosovo (Washington, DC, Brookings Institution, 2000). The concept of war also looms large in two other recent books: Stephen Schwartz, Kosovo: Background to a War (London, Interpress, 2000), and Tim Judah, Kosovo: War and Revenge (New Haven, CT, and London, Yale University Press, 2000).

19 Charles F. Doran, 'The Structural Turbulence of International Affairs', Survival, vol. 41, no. 2 (summer 1999).

20 Jenny Edkins, 'Sovereign Power, Zones of Indistinction, and the Camp', Alternatives, vol. 25, no. 1 (January-March 2000).

21 See chapter 2, by Peter van Ham, for a similar argument.

22 This is also the view which has been taken by the Federal Republic of Yugoslavia itself. See 'NATO Aggression Against the Federal Republic of Yugoslavia' (Belgrade, Federal Ministry of Foreign Affairs, May 2000). 
23 Michael Ignatieff, Virtual War: Kosovo and Beyond (London, Chatto \& Windus, 2000), p. 214.

24 Ibid., p. 215.

25 Michael Shapiro, 'Sovereignty and the Exchange of Orders in Modernity', Alternatives, vol. 16, no. 4 (October 1991).

26 NATO, press release, 041/1999.

27 Ulrich Beck, 'Über den postnationalen Krieg', Blätter für deutsche und internationale Politik, vol. 44, no. 8 (July 1999), p. 985.

28 Ibid., p. 987. See also Slavoj Zizek, 'Die Doppelte Erpressung', Die Zeit, 31 March 1999.

29 Andreas Behnke, "'Postmodernising" Security', paper presented at the ECPR Joint Sessions, Mannheim, 26-31 March 1999.

30 Beck, 'Über den postnationalen Krieg', p. 989.

31 Amnesty International, “'Collateral Damage” or Unlawful Killings?' (June 2000).

32 Behnke, " "Postmodernising" Security'.

33 Adam Roberts, 'NATO's "Humanitarian War" Over Kosovo', Survival, vol. 41, no. 3 (August 1999). 